Aykut Gürçağlar

\title{
Landscapes of Istanbul as An Imaginary Oriental City Through The Eyes of English Painters
}

Keywords: Orientalism, Imaginary Istanbul landscapes, English painters

\section{The Making of the "Orient"}

Historical origins of the concepts of the East and West need a positioning of the Orient in eastern art and politics. The Orient alone as a concept, does not bear any meaning in itself. There has to be an Occident against which the Orient can be defined. Edward Said remarks, that both geographical and cultural entities - to say nothing of historical entities - such as locales, regions, geographical sectors (i.e. "Orient" and "Occident", are man-made. Therefore as much as the West itself, the Orient is an idea that has a history and a tradition of thought, imagery, and vocabulary that have given it reality and presence in and for the West (Said, 1995, 5).

An Islamised image of the Orient emerged in the Christian West in the Middle Ages. In the twelfth and thirteenth centuries Arabia was described as "on the fringe of the Christian world, a natural asylum for heretical outlaws," and that Mohammed was "a cunning apostate" (Daniel, 1960, 84 in: Said, 1995, 63-64). The Oriental world began to come somewhat closer to the Western world with the Crusades. The main reason why the West was involved in the Orient mainly had to do with the fact that the Middle East was regarded as the birth-place of Christianity. From the perspective of art history, it is difficult to describe a uniform view of the Orient in Western art in the Middle Ages (İnankur and Germaner, 1989, 11).

In the Middle Ages, the journey to the Orient had almost always been linked with the act of pilgrimage. Yet from the $15^{\text {th }}$ century onward, journeys to the Orient aimed at observing and evaluating Ottoman power. The opposition between the Orient and the West which Europe had begun to construct no longer rested entirely on religious differences, as had been the case earlier. This opposition started to rely increasingly on political relations (Hentsch, 1992, 65).

A significant figure marking the transformation in the Western view of the Orient was Guillaume Postel. Postel took up a study into the world of Islam, its social reality 
(Description de la Syrie, 1542; De la République des Turcs, 1560), its religion (Le livre de la concorde entre le Coran et les Evangiles, 1553), and its language (Arabic, which remained culturally dominant) and thus, pointed at a growing interest in the Orient which would not be motivated by religious fervour (Hentsch, 1992, 65). His works made Postel a precursor of European Orientalism which would discover an "Other" in the Orient which waited to be "devoured, then digested" (Postel, 1560, 76 in: Hentsch, $1992,68)$. The $17^{\text {th }}$ century took on a fresh view of the Orient, mainly stimulated by curiosity. This curiosity was reinforced and reproduced through the accounts of Western travellers who

were soon to return carrying texts in their baggage, as later they were to pry loose the stones themselves: the sculptures, the bas reliefs, the obelisks. But above all, they produced account of their own making, "relations" as they were then called, which became the raw material from which an Orient could be manufactured, then enriched with works on the history of its peoples (Arabs and Turks above all), which later led to attempted assemblages of the knowledge about the Orient (Hentsch, 1992, 85).

This curiosity, and the ensuing information gathered by travellers and western officials, largely sponsored by their states in their journeys to the Orient had inevitable reflections on literature and fine arts.

The publication of the tales of The Thousand and One Nights in Paris, in 1704, translated and presented by Antoine Galland spelled the beginnings of an Oriental vogue in French literature (Hentsch, 1992, 99).

\section{The Ottoman Empire as Part of the Orient}

The dominant element representing the Orient in the Western world starting with the Renaissance was the Ottoman Empire whose power was gradually rising at the time. This perspective did not have a strong impact on Western art until later. In painting, one could see cliché pictures of figures wearing turbans and Oriental costumes placed on European landscapes around the $15^{\text {th }}$ century. Painters of the time showed no particular attempt to describe the Orientals as they were in real life, because their main intention was to create an exotic effect. In painting and theatre, motifs were borrowed from the costumes of Turks, Persians, Tartars and Indians and were indiscriminately combined. Such hybrid creations had appeared in the works of the $15^{\text {th }}$ century artists Fra Angelico, Botticelli, and Filippino Lippi. Later, Veronese, Tiepolo and Tintoretto, although they had opportunity to study Turkish costumes, still preferred to render the Turk in the conventional manner. In the meantime, themes of Oriental origin such as Lot's Daughters, Salome's Dance, Batsheba, Adoration of the 
Magi were depicted within a Western setting instead of an Oriental surrounding (St. Clair, 1973, 10 in: İnankur and Germaner, 1989, 11).

The Turkish conquest of Constantinople brought the Orient closer to Europe both through the Byzantine intellectuals who migrated to the West and through the curiosity evoked by the Ottomans who set up an Islamic civilization in the city. During this time, the hero and saint figures carrying yataghans and khanjars became as frequent in Western painting as those dressed in antique attire. Gradually, those dressed in Oriental clothes came to represent infidels and merchants and started to be associated with both evil and extraordinary wealth. Venetian artists such as Gentile Bellini, Tiziano and Mansueti who had close ties with Istanbul since the Byzantine period, made most use of Oriental figures like janissaries, ambassadors with turban, and merchants dressed in caftans of Damascus fabric. Gentile Bellini who had been to Istanbul and Egypt created the paintings Portrait of Mahomet II Conqueror and Imperial Audience Given to the Venetian Ambassador at Cairo. The artist can be considered to be among the first Orientalist paintings. The fact that he did not depict any scenes of Ottoman daily life is further interesting (İnankur and Germaner, 1989, 11).

The Venetian Republic was the first state to establish ties between the Ottoman Empire and the western world. Venetian ambassadors, known by the title Bailo, served in Istanbul starting from the second half of the 15th century. Lucette Valensi explains that these Ottoman-Venetian relations "lasted until the end of the Venetian Republic excluding periods of war between the Sublime Port and Venice. Generally the term of office for ambassadors was two years. On their return, they were asked to submit a detailed report to be read in front of the Senate and the Duke, like other Bailo ambassadors completing their posts in large capitals"1 (Basched, 1862 in: Valensi, 1994, 16-17).

The Ottoman Empire, with its financial strength, its vast territories in Europe and robust military power reached its peak and became a fearful rival for the West in the $16^{\text {th }}$ century which marked the establishment of commercial relations with the West. Luxury goods which were imported from Turkey to Europe, introduced Ottoman culture and art to the West. During this time, Ottoman Empire did not allow cultural movements to enter the country and found it sufficient to import arms and commodities which were not produced in its lands. In the $16^{\text {th }}$ century kings of Europe began to send ambassadors to the Ottoman capital, while no ambassadors were sent to the West from the Ottoman Court. The West, which was growing more powerful around that time, extensively discovered the political, economic and military structures of the Ottoman Empire mainly due to the development in trade relations and the constantly growing number of Western merchants in the country (Arslan, 1992, 15).

1 The book is written originally in Italian. Here I use the Turkish translation. All translations from the Turkish into English are mine. 
The ambassadors and merchants who were sent to Istanbul for diplomatic and commercial missions brought artists with them and started a tradition that would continue until the $19^{\text {th }}$ century. These artists depicted imperial ceremonies, costumes and city views in watercolour, gouache and engraving. The depictions by these artists were printed in the form of albums in Europe and triggered an interest in the Ottoman Empire in the Western world. Pieter Coecke Van Aelst, Melchior Lorichs, Nicolas de Nicolay and Scorella were among the most renowned artists who visited Istanbul in the $16^{\text {th }}$ century. The books of travel depicting the Orient began to disseminate in the same century (Arslan, 1992, 15).

The $17^{\text {th }}$ century was an era when the Western view of the Orient gained a new dimension. The first Ottoman diplomatic mission sent to Paris, evoked a concentrated attention towards "the Turk" in the early $17^{\text {th }}$ century. This mission enabled Europeans to have direct contact with Ottomans, whom they had thus far only seen in pictures and books. The outcome of the diplomatic contacts were also visible in literature. The $17^{\text {th }}$ century books of travel describing the Ottoman Empire influenced French literature deeply. It was particularly in the early $17^{\text {th }}$ century that Turkish themes started emerging in Western literature. Bourgeois Gentilhomme by Molière and Bajazet by Racine were amongst the first books where the Turkish theme was used. Apart from literature, books related to Turkish history and language also became popular in this period (Arslan, 1992, 16).

The number of patrons sponsoring the orientalists increased to a great extent in $17^{\text {th }}$ century. Books about Turkish history by authors such as Baudier, Mazerai, du Verdier, Stochove, Chassepol, and Ricaut were published in the same era. An immense curiosity emerged for the Ottomans in French literature between 1670-1684 and Fr. Bernier, J.B. Tavernier, Thevenot, d'Arvieux, Chardin and Lucas travelled to Asia Minor and published their memoirs (Parla, 1985, 19). Rembrandt was the most eminent representative of the Oriental vogue which spread to the whole of Europe in the post-Renaissance period through diplomatic contacts, wars and trade. Rembrandt copied Mongolian miniatures and collected Turkish arms and Persian rugs. Oriental images can be found in most of his paintings. Already in this period, Van Dyck painted Sir Robert Sherley with a large turban on his head and offered an interesting example of the British vogue for Oriental clothes. In the meantime, in his Adoration of the Magi Rubens depicted Flemish figures in clothes that identified them with Ottoman rulers (İnankur and Germaner, 1989, 21). A significant growth was observed in the number of painters and the travellers visiting the Orient in the $17^{\text {th }}$ century. By commissioning and patronizing artists who travelled to the Orient, collectors and the noblesse played an important role in encouraging artistic travels to the Orient. Georges de la Chapelle, Grelot, Cornelius de Bruyn, G. H. Van Essen were amongst the leading painters in 
this century who visited Istanbul and produced engravings depicting city views and Ottoman dresses (Arslan, 1992, 16). Ottoman military and political power began to show a weakness in the $17^{\text {th }}$ century. In this period European influence over political and economic issues became visible, which in turn, required the Ottoman Empire to improve its relations with Europe.

Sultan Ahmed III sent a diplomatic mission to France in the early $18^{\text {th }}$ century led by Yirmisekiz Çelebi Mehmed Efendi who was to play an important role in the relations between Turkey and France (Arslan, 1992, 16). Istanbul became a popular city for European artists, because of its growing diplomatic and cultural contact with Europe as well as its geographical location. In the $18^{\text {th }}$ century artists like Van Mour, Liotard, Carrey, de Favray, Hilair, Mayer and Melling, called "The Bosphorus Painters", worked in Istanbul apart from artists employed by European embassies (Boppe, 1911). In the late $18^{\text {th }}$ century most of the European aristocrats were trained in painting and enjoyed to paint the views of the places they visited personally. They were sometimes accompanied by professional painters who were trained as architects and who were interested in the Hellenistic heritage. These artists were mainly interested in architectural details and showed no effort to depict the daily life in Islamic countries. They can be considered as parts of the exoticism vogue which paid no attention to reality and accuracy. The late $18^{\text {th }}$ century was the golden age of engraving. The engravings depicting Oriental cities were often made after the drawings of renowned or less known artists completed on the spot. Exotic albums encouraged a passion for $\hat{a}$ la Turque costumes and glittering Oriental architecture (İnankur and Germaner, 1989, $18,19)$.

Imaginary exotic Istanbul landscapes which may be defined as a kind of capriccio were made in the $18^{\text {th }}$ century. Yet besides such imaginary depictions of the city, after Lady Mary W. Montagu's Istanbul letters were printed, there emerged a tendency to create realistic depictions of the Orient.

\section{The Origins of Orientalist Painting}

Exoticism gave place to Orientalism in the $19^{\text {th }}$ century. The rise of Orientalism has been associated with the rise of colonialism in Europe. France and England colonized Egypt and North Africa with political and commercial motives. The War of Independence in Greece, the wish to establish an autonomous state under British rule in Egypt, the western-inspired reforms which took place in the Ottoman Empire, and the construction of the Baghdad Railway and the Suez Channel were some of the factors underlying these motives. Orientalist painting grew in France and England within this colonialist environment. Growing awareness of the rich natural 
resources of the Orient, the emergence of the Orient as a market, the development of the means of transportation and the rise in the general interest towards Islamic culture were the major factors in the flourishing of the Orientalist movement in art. The most comprehensive and systematic attempt which started these affairs, turned out to be Napoleon's Egyptian Expedition in 1798. This expedition is regarded as the beginning of Orientalism. The first scientific institution to study the Orient was the Institut d'Egypt of Napoleon. Silvestre de Sacy, Ernest Renan and Edward William Lane were the first figures to analyse Orientalism within a logical and rationalist framework. Société Asiatique, Royal Asiatic Society and American Oriental Society were founded respectively in 1822, 1823 and 1842, while works such as Chrestomatie Arab by Silvestre de Sacy, Histoire Générale et Systeme Comparé des Langues Sémitique by Ernest Renan and An Account of the Manners and Customs of the Modern Egyptian by Edward William Lane made Orientalism an academic subject (İnankur and Germaner, 1989, 19).

There was no school of Orientalist painting; the pictures were linked thematically rather than stylistically (Thornton, 1983, 13). The French political and commercial domination in the Orient made Paris a leading capital of Orientalism. Industrializing Western cities lost their charm for artists who felt an urge to travel in the Orient. The French and British governments attached artists to military, diplomatic and scientific missions and sent them to countries around the Mediterranean basin, Palestine, India and the Ottoman Empire.

In the early $19^{\text {th }}$ century French painters adopted a visionary approach in their Orientalist paintings. The Realism movement which emerged in the second half of the $19^{\text {th }}$ century in France, enabled the painters who travelled in the Orient to see local people, their costumes and manners in a realist perspective, and to depict Oriental topics realistically (İnankur and Germaner, 1989, 23). By 1870s, the British and French were no longer enjoying a virtual monopoly over Orientalist painting.

Topics of the Orientalist painting can be classified into two: compositions with human figures and compositions with landscapes. Compositions with human figures consisted of a series of contexts where human figures were foregrounded. Battle scenes displayed the "savageness" and the cruelty of the Oriental peoples while Western oppression of the Orientals was not in any way reflected. Eroticism was another popular subject for Western artists. Scenes of the Harem, of the Turkish bath and of the slave market were instruments which served to quench the passion for eroticism in most Western paintings. These paintings, however, were presented to the Western spectators as documentary illustration with factual value. Harem and Turkish bath scenes in which Oriental women were gloriously displayed were especially attractive 
to Western spectators, mainly due to the fact that no Western visitor had ever been allowed to come into these places. Although painters had their point of departure at the realistic descriptions or written sources about Oriental Harem and Turkish baths, they made use of models and sometimes resorted to their imagination in completing their compositions. The bright sun light, spectacular Islamic architecture and its rich decoration, picturesque streets and people in colourful and strange Oriental costumes deeply impressed the painters and led them to depict their paintings in ethnographic realism (İnankur and Germaner, 1989, 42, 44).

Landscapes of nature in the Western painting were topographical in the early $19^{\text {th }}$ century but becoming gradually more picturesque towards the end of the century. Topographical landscapes started to develop in the $18^{\text {th }}$ century and took its subjects from ancient cities and monuments. The early landscape artists produced albums based on archaeological finds and used various printing techniques. The albums which were printed in many languages supplied material to early $19^{\text {th }}$ century painters while they represented the "Orient" for Western eyes. William Pears, William Bartlett, Thomas Allom, William Purser, Willam Page, Luigi Mayer were among the most renowned topographic landscape painters (İnankur and Germaner, 1989, 44, 47).

\section{British-Ottoman Relations}

The presence of permanent embassies in Constantinople from the mid-sixteenth century, soon after their establishment in Western capitals, shows that, in diplomatic terms, the Ottoman Empire was part of Europe. Ambassadors there were not treated as aliens, like ambassadors in Moscow before Peter the Great and after 1918. More than elsewhere, ambassadors played a role in the internal life of the capital, as well as in the external relations of the Empire (Mansel, 1995, 189).

Tülay Reyhanl 1 who studied life in $16^{\text {th }}$ century Istanbul as recorded in British travelogues suggests that the British had commercial and political reasons for approaching the Ottomans. These reasons mainly included establishing good relations with the Ottoman Empire which held the key posts on Oriental trade roads and ruled half of Europe and the Mediterranean in the $16^{\text {th }}$ century. Britain wished to use this power against Spain, and to free themselves from trading under French flag which had been formerly given commercial concessions by the Ottoman Empire. Furthermore, new markets were sought for British goods (Braudel, 1972; Kütükoğlu, 1974; Parry, 1976 in: Reyhanl, 1983, 14). Merchant Anthony Jenkinson was the first British subject who took the initiative to do free trade with the Ottomans. Suleiman the Magnificent had given him commercial concessions while he stayed in Haleppo to spend the winter of 1553 during his campaign against Persia. But the concessions granted were 
not used for 20 years and lost their validity. After a 20 year gap, Richard Staper and Sir Edward Osborne decided to renew the rights and to develop the relations between Britain and the Ottoman Empire. Upon William Harborne's arrival in Istanbul as Queen Elisabeth's agent in 1578, British-Ottoman relations gained an official aspect (Skilliter, 1977 in: Reyhanl, 1983, 14). Meanwhile, Turkey Company was established by British merchants on 11 September 1581. The company, it has been reported, was richer than India Company between the late $16^{\text {th }}$ and early $17^{\text {th }}$ centuries. This was the company which took the first step towards the long-lasting British-Ottoman relations. ${ }^{2}$ The company in which some 12 merchants like E. Osborne, R. Staper, T. Smith, W. Garret operated, was obliged to send out a certain number of ships every year and to pay 1500 Pounds Sterling per year. ${ }^{3}$ Sultan Murad III prepared an imperial edict which permitted British merchants in the Ottoman Empire to have commercial concessions in 1580. William Harborne arrived in Istanbul as British ambassador in 1583. His arrival was not to the liking of Venetians and the French who sought various solutions to prevent the British ambassador from setting up close ties with the Imperial Palace. ${ }^{4}$ William Harborne during his ambassadorship in the Sublime Porte continued commercial activities in the Ottoman Empire and sent some merchants to Chios, Crete and Zanta for trading (Skilliter, 1977, 113-114 in: Reyhanl, 1983, 15). Harborne's successor Barton further strengthened the relations between Britain and the Imperial Palace. He made an effort to encourage the Ottoman fleet to set sail into the Mediterranean so as to use Ottoman power against Spain. He joined the Hungarian campaign which was led by Sultan Mehmed III. This event pleased Ottomans, yet it also provoked some negative response in the Christian world. Barton was replaced by Henry Lello during whose term of office capitulations granted to the British merchants were enlarged with new provisions introduced in 1601 (Reyhanl, $1983,15)$.

British painters who visited Istanbul especially from the early $16^{\text {th }}$ century began to produce travel books which were based on their observations and studies. Tülay Reyhanlı writes that the British who came to visit the city, first stayed at Ahmet Paşa Konağ 1 which was used as the British Embassy and then moved to the building whose land is occupied by the English Palace today. Reyhanlı also remarks that the British who visited Istanbul in the $16^{\text {th }}$ century mainly consisted of merchant-diplomats, travellers, captives and artists (Reyhanl1, 1983, 23).

2 About this subject see Sir F. Walshingham's Report, PRO [Public Record Office, London], SP [State Papers], 12/44, Skilliter (1977, 27-32).

3 About this topic see Skilliter (1977, 179-82); Wood (1935); Kurat (1953); Kütükoğlu (1974, 13-14 in: Reyhanl, 1983, 14).

4 See the letters sent from Venetian Ambassador G. F. Moresini to the Venetian Duke and Senate, CSP in the PRO, (Venetian), 1581-1591, $5^{\text {th }}$ April 1583, 19 $9^{\text {th }}$ April 1583, $6^{\text {th }}$ March 1583, $3^{\text {rd }}$ April 1584 in: Reyhanlı $(1983,15)$. 
This paper will present and analyse a series of paintings produced by British artists during the four centuries of British-Ottoman relations with special focus on the $19^{\text {th }}$ century. These artists were not all professional painters and their excursions to Constantinople did not always have artistic objectives. It will become evident that the economic, political and military ties between Britain and the Ottoman capital constituted significant factors leading to artistic production, which in turn, came to represent the Orient in the Western world.

\section{Thomas Morgan's Saint Sophia}

The first painting I will present is Saint Sophia by Thomas Morgan (Figure 1). The illustration is kept in the British Library, London and is registered to Sloane MSS5294, art 92. It is in watercolour and is dated to the second half of $16^{\text {th }}$ century. Thomas Morgan was a seaman who spent 15 years in the Ottoman Empire during the reign of Sultan Murat III as a captive. Although there is no data about Thomas Morgan it may be suggested that he was employed on a British ship which was captured in the Mediterranean either before capitulations were granted to British merchants or in the beginning of the Ottoman-British relations (Reyhanlı, 1983, 31).

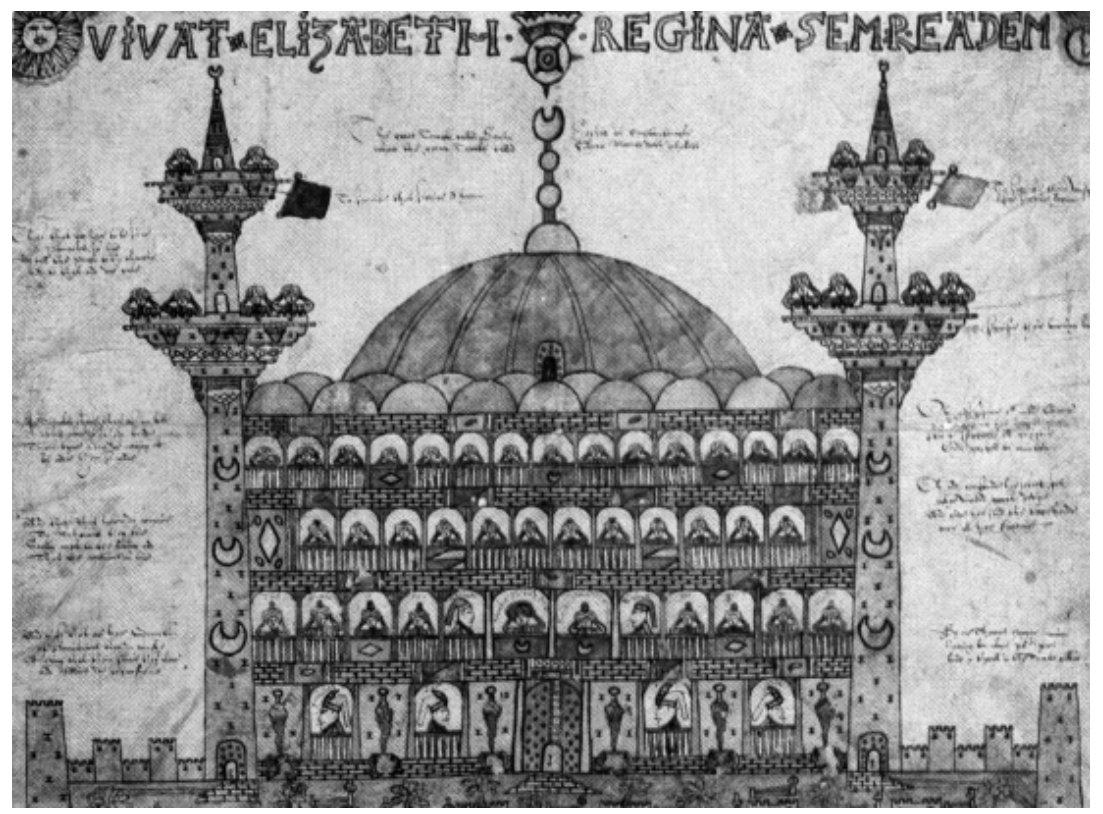

Figure 1: Thomas Morgan, Saint Sophia, ca. 1550, London, Brit. Mus. Sloane MSS. 5294, art. 92

Source: Reyhanlı, 1983, pl. 78 
Saint Sophia nearly covers the whole surface of the painting. On the upper part of the illustration, the inscription Vivat Elizabeth Regina Semreadem appears indicating that the picture is dedicated to Queen Elisabeth. There is a second Latin inscription under the first one which reads: Saint Sophia temple is located in Istanbul where the Grand Turk Sultan Murad lives. The artist's signature stands on the same line. The depiction shows Saint Sophia as a domed edifice in central plan with two minarets. The central dome is painted in pink. Smaller domes which were arranged in two rows and placed on the point where the central dome was attached to the main body of the edifice, are painted in green and yellow. The façade consists of four storeys. Each storey has windows supported by slender columns on the lower level and round arches on the upper level. There are janissary heads which are depicted from the profile standing on either side of the bronze gate on the first floor. On the second floor, the Lords of his Eunuke (or chief eunuchs) and Janichers (or janissaries) are placed on both sides. In the middle of the second floor the High priest (or Sheikal-Islam) wearing a green turban stands on the left side of the composition and Sultan Murat III sits next to him. On the other two floors, there are figures with turbans with their hands on either side of their heads. These figures are shown frontally. The minarets have two balconies. There are four muezzins on the lower balconies and two on the upper balconies depicted while calling to prayer. The balconies are decorated with oil lamps. The spires are placed right above the second balconies. Three crescent motifs of different sizes, the largest arranged at the bottom, are placed on the façade of the minarets. The crescents are gilded. There are several inscriptions near the minarets. T. Reyhanl writes that these insciptions "explain that the muezzins call Muslims to prayer, that a black flag mounted on the second balcony announces that the prayer has begun, and that fountains cleanse believers of their sins" (Reyhanl, 1983, 38). The edifice is surrounded by a wall. Reyhanl suggests that this wall represents the buttresses supporting the building constructed by the famous Ottoman architect Sinan (Reyhanl, 1983, 38). In my opinion, the wall represents the walls surrounding the building and not the buttresses. Morgan also included the courtyard in the painting with displays some of Ottoman tombs bearing turbans in various dimensions in the form of sarcophagi. Stylized trees have been laid among the ramparts, which are placed at the foreground of the composition.

The painting was made in miniature style. The colours used in the painting were spread on the surface evenly and symmetrically, while linear and colour perspectives are not employed at all. It can be suggested that Morgan's artistic ability was that of an amateur. The fact that Thomas Morgan depicted Saint Sophia with a central dome means that he had a chance to see the building from the exterior at least once. It is not 
clear when Morgan made the painting. He either made the painting while he was in the Ottoman capital or after his return to Great Britain. He must have been familiar with the customs and life styles of the Ottomans as proven by the text he wrote on the painting where he explains how the Ottoman Sultan did his Friday Prayer and the sermon to the believers. He adopted a realist manner in the details, e.g. in the hats of janissaries and turbans of high rank officials. But the building in general is a product of a fictive composition. Morgan worked like a miniaturist. Pyramid shaped minarets with crescent motifs on top are symbols which were continuously copied by Western painters. In fact these motifs symbolize the Islamic creed and are placed on the standards which stand on minaret spires, instead of minaret bodies. In the $16^{\text {th }}$ and $17^{\text {th }}$ centuries Western artists were keen on seeing and depicting the Ottoman minarets as pyramidal forms. Thomas Morgan placed the spires right above the second balconies of the minarets. This indicates that the painter either failed to perceive the form of an Ottoman minaret or forgot how a minaret looked like. We can also suggest that Thomas Morgan, like other Western painters, tried to use a foreign architectural element and made it familiar to his target audience by transforming it into a pyramidal form. The artist organized the building's façade into four storeys to be able to show how people hierarchically took their seats in the edifice. Even if this arrangement is the product of the artist's imagination, his goal appears to have been to illustrate the building's function, to define the building and to explain it.

During the $19^{\text {th }}$ century the Western artistic view of the Orient gained a different dimension along with Western policy and literature. We will look at the $19^{\text {th }}$ century examples after Thomas Morgan's work. The second artist is William James Muller and his work Imperial Caique is in a recreation area (Figure 2). This picture took its place among the objects displayed to be sold in the auction organized by Maçka Mezat Antikacılık A. Ş. on $1^{\text {st }}$ March 1992 in Istanbul (Anonymus, 1992, 31). The painting is oil on panel and is dated $1843(18 \times 15 \mathrm{~cm})$. William James Muller was born in Bristol in 1812 and died in 1845 in the same town. He became a well-known painter of figures and landscapes. His father, of Prussian origin, became a curator of the British Museum. The artist became the pupil of G. B. Payne (Bénézit, 1956, 268). He exhibited at the Royal Academy in 1833. He traveled in Greece and Egypt in 1838. He made his best paintings during the research trip to Lycia with Sir Charles Fellows in 1843. Archeologist Sir Charles Fellows located some ancient cities like Xantos, Pinara and Tlos in Anatolia. The findings brought from these ancient sites, Sir Charles Fellows' archive and watercolors of Lycia made by W. J. Muller are today on display at the British Museum. A very few of his sketches were transferred into oil on canvas. Because of his illness he was unable to realize commissions (Thornton, 1983, 264). 


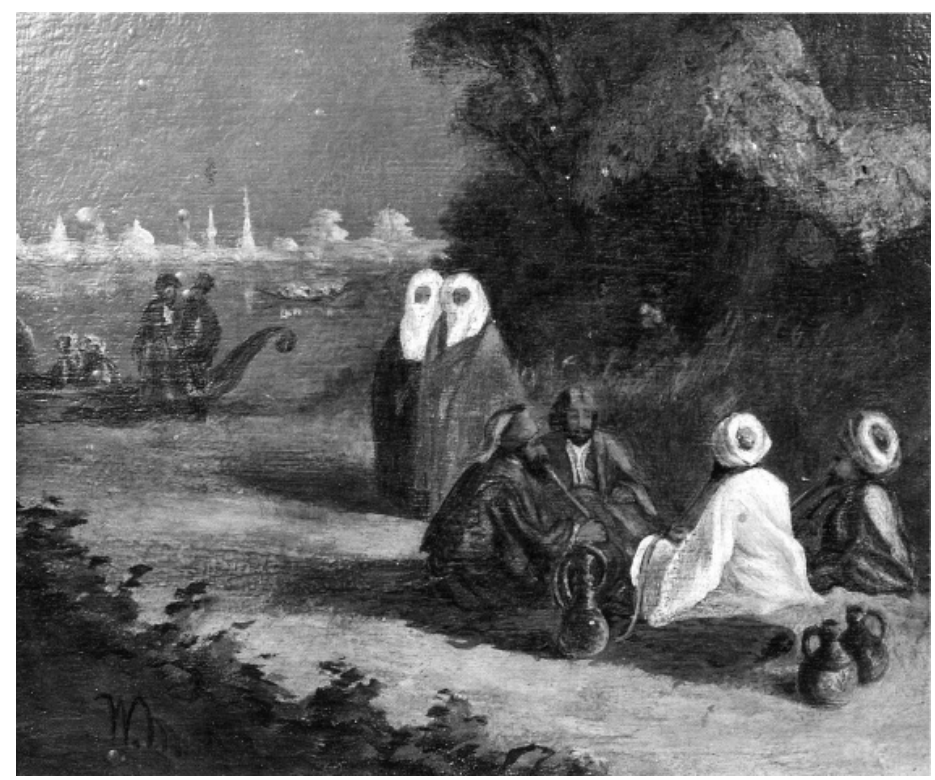

Figure 2: William James Muller, Imperial Caique is in a Recreation Area, 1843, Istanbul, Private collection

Source: Maçka Mezat Müzayede, 31

Even though W. J. Muller worked in Anatolia with Sir Charles Fellows, we do not know whether he visited Istanbul. But, since Sir Charles Fellows went to Istanbul to request a permission for his excavations in Lycia, the artist might have accompanied him to visit the Ottoman capital.

There are scrub plants which cover a triangular space on the left hand corner of the composition. The eyes of spectators enter the painting from this point. The four male figures are placed from the right hand corner to the foreground of the composition. Two of them wear turbans. The one on the left is shown from behind. This male figure wears a long cape, and sits cross-legged, smokes a water-pipe which stands next to him. The other figure standing next to this one is shown from the profile, he lays his body on the ground, wears a long jacket and smokes a water-pipe. The third male figure is placed on the left side of the other two figures. This bearded figure wears baggy trousers, sleeveless jacket and long tasseled fez, and smokes a water-pipe. Fourth figure sits cross-legged next to the previous male figure and wears a long cape on a white shirt and a gold embroidered sleeveless jacket. This one has a beard and he wears long tasseled fez. There are two vessels behind the four male figures and their surfaces are illuminated with a light which comes from the right side of the composition. On the right side of the four male figures, two standing female figures, which are placed on 
the line extending through the background of the composition, can be seen. The one who is on the right wears light blue, the other wears dark brown over garments. Both of them rap white scarves around their heads. These scarves cover their faces except their eyes.

Behind the figure groups of two and four, from the right side to the upper end of the composition, there are a group of plants, a tree and a green tract made with thick brush strokes. There are two male figures, one of them is shown from the profile, the other from the front. These figures which are illustrated as brown spots, wear long jackets. The one standing on the left holds a rug in his hand and the other holds his sword. Both of them wear long caps. Behind those figures, a coastal view is placed which makes the background of the painting. The male figures stand in front of an imperial caique. The figures in the caique are blurred.

Istanbul view is placed in the background as a line which divides the sky and the sea from each other. The landscape consists of white, thick brush strokes. Istanbul is seen as a city silhouette of minarets, towers and domes.

The artist used a romantic technique for depicting the Bosphorus shores, showing the inhabitants of the city amusing themselves by the shores and illustrating their costumes and their habits within the panorama of the Ottoman capital. However, many prejudices and subjective concerns can be found in this picture. The four males are enjoying themselves by the Bosphorus shores. Two of them wear long fezes which became popular in the reign of Sultan Abdülmecit. They smoke waterpipe. Two pitchers behind them imply they drink alcoholic drinks. Two women standing next to them must be their viwes. There are also two figures standing by the shore, and these figures must be waiting to serve the sitting male figures. If the painting's title is considered, one of these male figure must be the Ottoman Sultan. The figure resembling Sultan Abdülmecit wears a fez, a long cape and sits cross-legged. The other male figures around him represent viziers to the Sultan. The standing women have been depicted as the concubines of the Ottoman ruler. The imperial caique is at anchor on the shore and two male servants await by the shore. Istanbul as a white silhouette can be seen in the background. This is an imaginary and an orientalist view of the city. Everything in the composition is prepared in detail and in realistic illustration. We can see the men who are attired in long capes, wearing fezs and turbans, bearded, and smoking water-pipes. On the contrary, the women are depicted in yashmaks, enveloping their heads, faces and necks in white gauzes, and in feredje, enfolding their forms down to the feet (Van Millingen, 1906, 255). They are standing and they look as if they are at the service of the men, because in Oriental society in general and in the Ottoman Empire, women were not equal to 
men to the extent that some women were sold and purchased on the slave markets as a commodity until 1846, when slavery was banned (Sakaoğlu, 1994, 202). By looking at this painting we can arrive at the conclusion that the Ottomans spent their time on the shores of the Bosphorus idling, smoking water-pipes and courting their harem like their Sultan does. W. J. Muller probably prepared the painting by making use of the notes and sketches he took down when he was in Istanbul. And he must have resorted to his imagination to finish the composition as even in the time of Sultan Abdulmecit, when the relations between the two sexes became emancipated to a certain extent, the etiquette of the court did not allow an Ottoman Sultan to have the ladies of imperial harem standing before the viziers. Istanbul landscape which composes the background of the composition can never be seen from any point in the Bosphorus. The artist was not familiar with the Ottoman culture and architecture so that he attempted to depict them the way would like the others to understand them. The domes and minarets are stylized from their original appearance and the artist installed them in the shores of the imaginary Bosphorus by transfroming them into the architectural forms in The One Thousand and One Nights and Mamelukid buildings in the valley of the Nile which he had seen during his trip to Egypt. The perception of imaginary Istanbul landscape of the artist is a kind of cover that seems to veil the realistic and documental description of the city. Unfamiliarity with the Ottoman customs and indifference to the vernacular architecture both make the imaginary structure in this case.

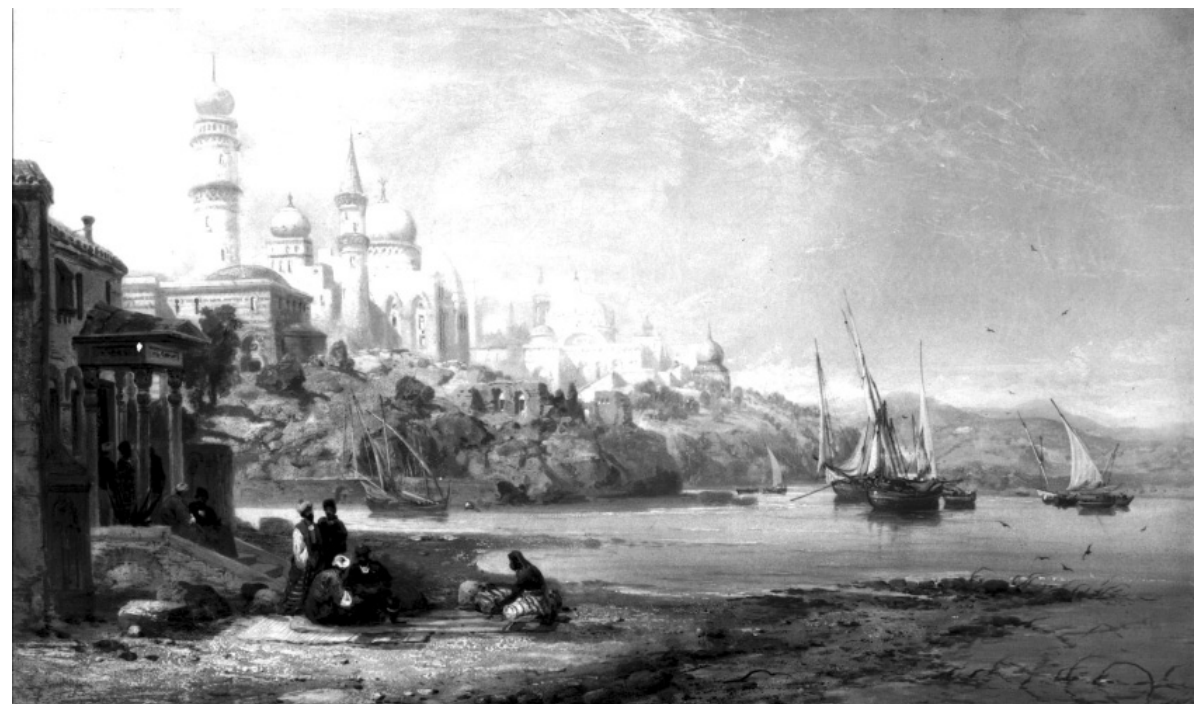

Figure 3: James Webb, Constantinople, 1874, Private collection Photo: Sotheby's, London 
The third example bears the name Constantinople (Figure 3). It is dated to 1874 and painted by James Webb. The painting is oil on canvas $(61 \mathrm{x} 102 \mathrm{~cm})$. It was sold for 13.000 Pounds in the auction organized by Sotheby's, London on 30 ${ }^{\text {th }}$ March 1994.

James Webb (1825-1895) was an English marine and landscape painter. J. Webb produced his paintings in an independently naturalistic style. As a prolific painter he exhibited between 1850 and 1888 at Royal Academy, British Academy and Suffolk Street in London. His landscapes are kept in famous museums such as Sea shore Boats and Fishermen (Victoria and Albert Museum), Mont Saint Michel (Tate Gallery) and The View of Constantinople (Glasgow Museum) (Bénézit, 1955, 685).

The foreground of the composition is rather long and large. Here, a coast line stretches towards the centre of the foreground. There is the sloping roof of a building whose greater part is taken out from the painting, on the left hand corner. A stone pier which is adorned with a pointed arch on its façade appears to be a fountain. It has a pointed spear on top, and is adjoined to the building. Another building, on the right of that edifice, is placed diagonally to the composition. It has two storeys and has round arched windows which are supported by four columns. Its portico has a triangular pediment which is covered with a sloping roof. The capitals of the portico are globe shaped. There are two male figures of which one is shown from the front and the other from the back. One of these standing male figures wears a fez, a cloak, while the other wears a turban, a jacket and a pair of baggy trousers. There are two other male figures in front of them seated on the stairs which reach the portico. One of those wears a turban, a cloak while the other wears fez and a pair of baggy trousers. There are four male figures on a rug at the bottom of the stairs. Two of them sit and the other two stand on the rug. One of the standing figures who is shown in the semi-profile, is bearded, wears a long sleeved shirt, and jacket, a pair of baggy trousers and a turban, while the other is shown from the front and wears fez, a long cape and has a bearded face. One of the sitting figures is shown from the back and the other from the front. Opposite the four male figures an African woman sits on her knees. She is shown from the profile and she wears a tight shirt and a pair of baggy trousers, her head is covered with a scarf. She holds two bundles.

A neck of land which is limited by the sea and sail boats, a number of caiques are seen on the background. This neck of land is a kind of promontory which is covered with an intensive vegetation. There ruins of round arches and brick and stone textured wall fragments belonging to an ancient building stand on the slope which rises from one of the inlets of the promontory. On top of the promontory there are several buildings arranged in a row side by side. One of those building stands in the front. It is a two storey building and its brick and stone textured portico is adorned 
with a horseshoe arch and crowned with two small and low domes. The building has a polygonal apse which is covered with a semi-circular small dome on its façade facing the sea. Behind the building, on the left, there is a tower which is in a circular plan and constructed with brick and stone. It is crowned with an onion shaped dome and there are windows on its façade and a balcony which appears to be a balcony of a minaret. On the right of the tower there is a building which is covered with an onion shaped dome on which stands a three stepped drum. A minaret is placed to the right of the edifice. The minaret is in a circular form and it has windows on its façade. It is covered with a pointed spire on top. Behind the minaret, there is a building which is decorated with a row of pointed arched windows on its façade. Its onion shaped dome which ends with a standard, stands on a drum which is adorned with a high relief border of round arches. Another building is adjoined to this edifice. It is in a central plan and is covered with an elliptical dome. On the right of this group of buildings there is a building which is in a rectangular plan. It has a square plan portico. The portico is covered with a dome and its façade fluted with round arches. The building is covered with a large dome with a lantern that stands on a drum which is adorned with a single large round arch. A tomb-like, square planned and onion shaped domed building stands in front of this edifice. Behind these two buildings a tower which is covered with a conical spire can be seen. In the rest of the background hills continuously stretch to the right end of the composition.

This painting can be compared with View of Constantinople by Felix P. Ziem because both paintings show many resemblances (Figure 4). These resemblances, putting a coastal view in the foreground, a building with a sloping roof on the left and a neck of land in the background, are attention-grabbing. However, F. P. Ziem used a single religious buildings commanding the city, while J. Webb used two different groups of building on the promontory. F. P. Ziem's coastal view presents the city occupied with the intensive buildings, while J. Webb employed a few ruins of old buildings and green texture so as to try to alter the city view into a grotesque appearance. There is an absence of time and space in the J. Webb's composition. The costumes of the figures in the Webb's painting were borrowed from the engravings which are placed in travel books or costume albums about the Ottoman Empire. The characteristics of the buildings were borrowed from the architecture of the Ottoman world. Onion shaped domes reflect Indo-Mughal architecture, globe shaped capitals are derived from Persian architecture, the pointed arched windows are borrowed from Gothic architecture, and central planned buildings whose domes stand on a drum and end with a lantern are derived from the central planned churches of Renaissance age. The building which is covered with a sloping dome reflects the features of vernacular architecture which can be found in any Mediterranean city of the $19^{\text {th }}$ century. 


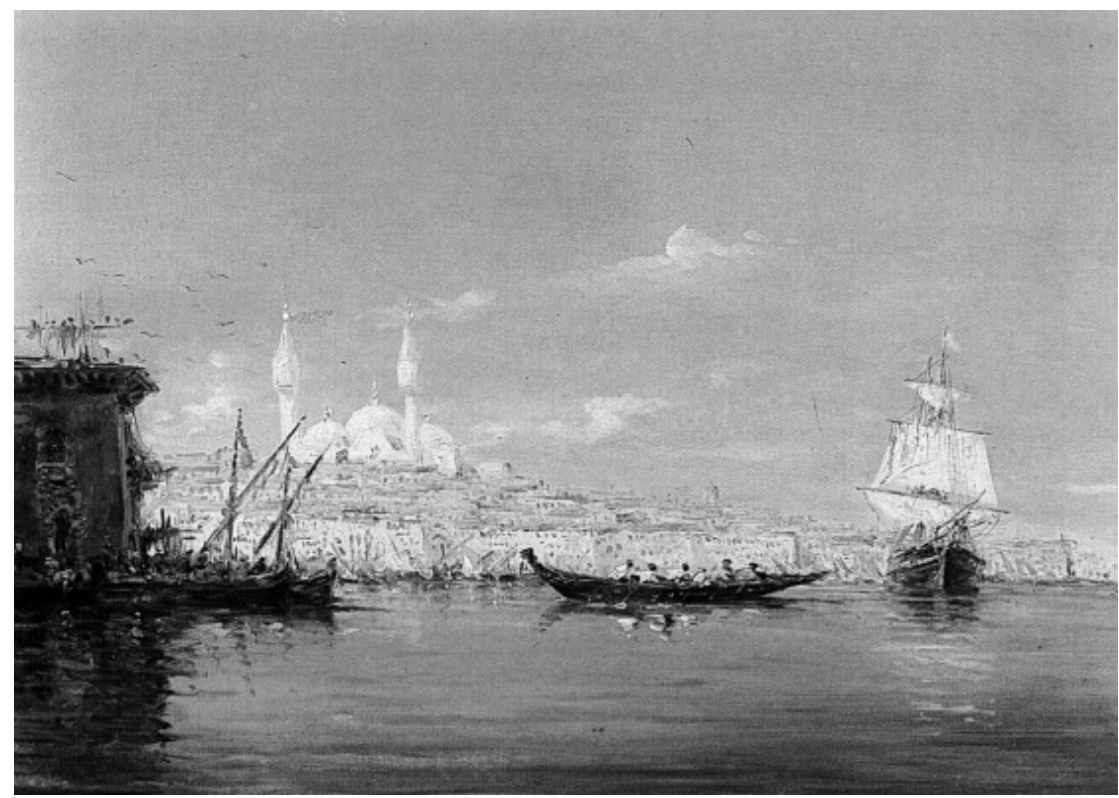

Figure 4: Felix Philibert Ziem, View of Constantinople, late $19^{\text {th }}$ century, Istanbul, Private collection

Source: İnankur and Germaner, 1989, pl. 95

The only element which refers to Istanbul is that the city is located by the sea. J. Webb, instead of using photographs of the city or engravings in the travel books, preferred to employ his imagination for making the depiction of an Oriental city, in an era when the photography was spreading throughout Europe. In this painting J. Webb depicted such an Oriental city in which the idle Orientals lived, as it is surrounded by the atmosphere of the mess of architectural styles. The atmosphere is domesticated with the Renaissance domes, the bell towers and the ruins of ancient buildings. However, the expression of Istanbul through the eyes of a Western artist is not that of a city which is adorned with mere Ottoman architecture, but it is adorned with the buildings covered with onion shaped domes recalling Indo-Mughal architecture. The artist made his composition with balanced brush strokes, and the vertical and the horizontal lines which form the structure of the composition are also well-balanced, but the left side of the composition is more concentrated with respect to the right. It is a Romantic view of an imaginary Oriental city.

These conclusions can be made from the illustrations studied.

Istanbul became a capital city which was paid great attention by the Western world since the Middle Ages from the political, religious and economic perspectives. 
The first illustrated source describing the Middle East is Sanctae Peregrinationes by Bernhardt von Breydenbach, printed in 1486. This book is about the pilgrimage trip of Archbishop of Mainz and its wood-cut illustration was made by Erhard Reuwich. The pilgrims spent a couple of days in Constantinople on the way to Jerusalem to see the relics which were kept in the churches of the city in this age. Some of them depicted Istanbul. These depictions illustrate the city in the realistic point of view and some show a Byzantine city which is a product of an imaginary construction. The abundance and variety of the depictions of the city can be seen in the $16^{\text {th }}$ century, but duplications from the similar patterns were made in the same period. There is a panoramic description of Istanbul divided into two unrelated parts in the first page of the book which is named Topographia Constantinopoleos et de Illius Antiquitatibus Libri Quatuorve de Bosphoro Thracio Libri Tres and is written by Pierre Gilles (Petrus Gyllius) in the same age. The lower part of the description is an Istanbul panorama. The panorama which makes the lower part of the two-sided description, was copied from the panoramas made and printed by Andrea Vavassore and F. Braun and G. Hogenberg. Andrea Vavassore in the first half of the $16^{\text {th }}$ century and F. Braun and G. Hogenberg in the second half of the same century printed the panorama of Istanbul based on the drawing which was made by an Italian painter who viewed the historical peninsula from Galata in 1480-90s. In this panorama and in the other variations pyramidal minarets, their horn-like standards and the streets of the city, which do not reflect the original streets of the town, are the imaginary productions of the painters and printers who were unfamiliar with the Ottoman architecture. More over, while Saint Sophia was altered to make it similar to Saint Mark's Cathedral in Venice in the earlier copies, the edifice was covered with a flat dome in the panorama which was placed on the first page of the book written by Pierre Gilles. Pieter Coecke van Aelst, Melchior Lorichs of Flensburg, Nicolas de Nicolay came to visit Istanbul in this century. The scenes of the people of the city and the city views made by these painters, it must be said, are realistic. The British point of view of Istanbul was represented by Thomas Morgan in the same century. Instead of making a topographical city view, he depicted Saint Sophia as one of the most significant religious and political symbols of the city. It was the most splendid monument of the world when the edifice was built. It has always been compared with the Solomon temple at Jerusalem in terms of its splendour. T. Morgan's painting of Saint Sophia is the mixture of imaginary and documentary elements. The structure of the edifice contains imaginary features but showing the Sultan's Friday Prayer in the mosque is a documentary feature.

With the colonization program of the Orientalism in the $19^{\text {th }}$ century imaginary Istanbul landscapes were added into the topics of the Orientalist painting. Among those painters who made imaginary Istanbul landscapes, some visited the city some even 
lived in it. For the Western travellers, Istanbul in the $19^{\text {th }}$ century, with its spectacular domed mosques, plenty of gardens, rundown houses, represented a picturesque view. In contrast to the Western cities, Istanbul has been viewed as a picturesque city completely. The places which were mostly chosen as the topic for the imaginary Istanbul landscapes were the Golden Horn, the Galata Bridge, and the Bosphorus. Many of the Western travellers entered the city from the sea side. In many of imaginary Istanbul landscapes these points of the city were altered with imaginary elements as if the city had been an Arabic city described in the One Thousand and One Nights. Some Western painters, as an escape from the reality, created an Oriental image, and the historical peninsula of Istanbul was transformed into the environment of W. J. Turner's Carthage. In such imaginary Istanbul landscapes, mosques adorned with triangular pediments and Corinthian columns, onion shaped domes or Baroque domes, bell towers and monumental piers carrying sculptures which combine the Orient and the Occident, can be seen. The mosques and the other buildings in the backgrounds were altered by adding architectural elements typical of Mamlukid and North African architecture or an environment was surrounded with classical architectural motifs resembling the Carthage of W. J. Muller in the imaginary landscapes of Istanbul. This case indicates the artists' disappointment with the Ottoman architecture. The Western painters did not see any difference between the Ottoman architecture and the North African architecture. However they found North African architecture more elaborated than the modest Ottoman architecture. They simply converted the Ottoman architecture to the North African architecture in order to get rid off their feeling of disappointment with the Ottoman architecture.

One of the most benefited sources from which the painters made imaginary Istanbul landscapes were the engravings of Istanbul views put into the travel books. Those views were treated as the most reliable documents about the appearance of the city until the photography became fashionable in the West. But, even in the Istanbul views by William Bartlett, Thomas Allom and Eugéne Flandin some imaginary conversions which have been remarked above, can be seen. There may be two reasons for this: either the painters made sketches on the spot and did not took all the details into consideration, then they completed the unfinished parts of the city views by employing the power of their imagination; or, the engravers who prepared the moulds for printing process, added imaginary elements to the original depiction. It can be said as a conclusion that the imaginary Istanbul landscapes were part of remaking of the Orient, and the Western painters among whom the British, became the creators and performers of that project. 


\section{Bibliography}

Anonymus. (1992), Maçka Mezat Antikacılık A.Ş. Müzayede 1 Mart 1992, İstanbul.

Arslan, Necla. (1992), Gravür ve Seyahatnamelerde İstanbul (18.Yüzyıl Sonu ve 19.Yüzyıl), İstanbul Büyükşehir Belediyesi Kültür İşleri Daire Başkanlığı Yayınları, İstanbul.

Baschet, Armand. (1862), La diplomatie vénitienne. Les princes de l'Europe au XVIIe siècle d’après les rapports des ambassadeurs vénitiens, Paris.

Bénézit, Emmanuel. (1955), “James Webb”, Dictionnaire critique et documentaire des Peintres, Sculpteurs, Dessinateurs et Graveurs de tous les temps et de tous les pays par un groupe d'écrivains spécialistes français et étrangers, vol. 6, Librairie Gründ, Paris, p. 685.

Bénézit, Emmanuel. (1956), “William James Muller”, Dictionnaire critique et documentaire des Peintres, Sculpteurs, Dessinateurs et Graveurs de tous les temps et de tous les pays par un groupe d'écrivains spécialistes français et étrangers, vol. 6, Librairie Gründ, Paris, p. 268.

Boppe, Auguste. (1911), Les Peintres du Bosphore Au Dix-Huitième Siecle, Librairie Hachette, Paris.

Braudel, F. (1972), The Mediterranean and the Mediterranean World in the Age of Philip II, 2 vols., (Translated by S. Reynolds), London.

Daniel, Norman. (1960), Islam and the West: The Making of an Image, Edinburgh: University Press.

De Rougemont, Denis. (1961), Vingt-huit siècles d'Europe, la conscience européenne à travers les textes d'Hésiode à nos jours, Payot, Paris.

Gibbon, Edward. The Decline and Fall of the Roman Empire, Vol. I, The Modern Library.

Grousset, René et Denicker, George. (1955), La Face de l’Asie, Payot, Paris.

Hammer, J. de. (1835-1840), Histoire de l'Empire Ottoman, 16 vols.

Hentsch, Thierry. (1992), Imagining the Middle East, (Translated by Fred A. Read), Black Rose Books Ltd., Montréal.

İnankur, Zeynep and Germaner, Semra. (1989), Oryantalizm ve Türkiye, Türk Kültürüne Hizmet Vakfı Sanat Yayınları, Istanbul.

Kurat, A. N. (1953), Türk-İngiliz Münasebetlerinin Başlangıcı ve Gelişmesi, 15531610, Ankara.

Kütükoğlu, B.M.S. (1974), Osmanlı-İngiliz İktisadi Münasebetleri I (1580-1838), Ankara. 
Mansel, Philip. (1995), Constantinople City of the World's Desire 1453-1924, John Murray, London.

Parla, Jale. (1985), Efendilik, Şarkiyatçılık, Kölelik, İletişim Yayınları, İstanbul.

Parry, V.J. (1976), “The Successors of Sulaiman, 1566-1617”, The History of the Ottoman Empire to 1730, (Ed. by M. Cook), Cambridge-London-New York, pp. 103-133.

Postel, Guillaume. (1560), De la République des Turcs:\& là ou (sic) l'occasion s'offrira, des meurs \& loy de tous Muhamedistes, A Poitiers, Par Enguilbert de Marnef.

Reyhanlı, Tülay. (1983), İngiliz Gezginlerine Göre XVI. Yüzyılda İstanbul'da Hayat, Kültür ve Turizm Bakanlığı Yayınları, Ankara.

Said, Edward, W. (1978), Orientalism, Pantheon, New York.

Said, Edward, W. (1995), Orientalism, Penguin Books, London.

Sakaoğlu, Necdcet. (1994), “Esir Ticareti”, Dünden Bugüne İstanbul Ansiklopedisi, vol.3, Kültür Bakanlığı ve Tarih Vakfı Ortak Yayını, İstanbul, pp. 201-202.

Siegfried, André. (1948), The Mediterranean, (Translated by Doris Hemming), Jonathon Cape, London.

Skilliter, S. (1977), William Harborne and the Trade with Turkey, 1578-1582, London.

St.Clair, Alexandrine, N. (1973), The Image of the Turk in Europe, The Metropolitan Museum of Art, New York.

Thévenot, Jean. (1980), Voyage du Levant, FM/La Découverte, Paris.

Thornton, Lynne. (1983), The Orientalists Painter-Travellers 1828-1908, ACR Edition, Paris.

Valensi, Lucette. (1994), Venedik ve Bâb-1 Âli Despot'un Doğuşu, (Translated by A. Turgut Arnas), Bağlam Yayıncılık, Istanbul.

Van Millingen, Alexander. (1906), Constantinople, A \& C Black, London.

Wood, A. (1935), A History of the Levant Company, Oxford. 
Aykut Gürçağlar

\section{Vedute Carigrada kot imaginarnega orientalskega mesta skozi oči britanskih slikarjev}

Ključne besede: orientalizem, carigrajske imaginarne vedute, angleški slikarji

Članek obravnava imaginarne carigrajske vedute dveh angleških slikarjev 19. stoletja ter jih postavlja v kontekst orientalizma in otomansko-britanskih stikov. Osredotoča se na analizo dveh ključnih slik obeh slikarjev. Britanski umetniki, ki so obiskali prestolnico otomanskega cesarstva, niso bili zmeraj poklicni slikarji in njihovi obiski Carigrada niso imeli zmeraj umetniških ciljev. Avtor razkriva, kako ekonomskim, političnim in vojaškim povezavam med Veliko Britanijo in prestolnico otomanskega cesarstva ni uspelo $\mathrm{v}$ zadostni meri definirati umetnostne produkcije, ki je vzpostavila podobo Orienta v Zahodnem svetu.

V prvem delu članek definira izoblikovanje in razumevanje pojma Orient na Zahodu. Nadaljuje $\mathrm{z}$ obravnavo politike Otomanskega imperija do Zahoda ter njegovih političnih, ekonomskih in umetnostnih vezi z Zahodno Evropo, prek katerih se poskuša vzpostaviti kot del Zahodnega sveta. $\mathrm{V}$ nadaljevanju avtor oriše zgodovinski razvoj orientalizma, zlasti odnosov med Veliko Britanijo in Otomanskim imperijem. V osrednjem delu se posveti analizi ene najzgodnejših vedut Carigrada, delu britanskega pomorščaka Thomasa Morgana in delom dveh britanskih slikarjev 19. stoletja. Raziskuje predvsem razloge za vključevanje imaginarnih elementov, za katere so na Zahodu verjeli, da so resnični in da predstavljajo obstoječe stanje $\mathrm{v}$ otomanski prestolnici. 